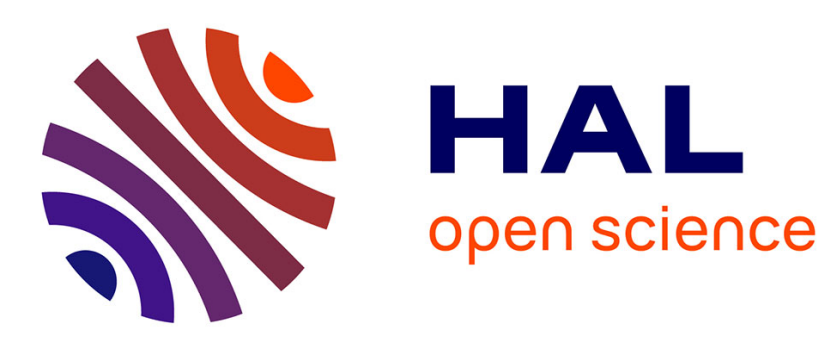

\title{
Rhythm, accentuation and final lengthening in French
}

\author{
Jacqueline Vaissière
}

\section{To cite this version:}

Jacqueline Vaissière. Rhythm, accentuation and final lengthening in French. J. Sundberg, L. Nord, \& R. Carlson. (Eds.). Music, Language, Speech and Brain, Macmillan Press, pp.108-120, 1991. halshs-00363980

\section{HAL Id: halshs-00363980 \\ https://shs.hal.science/halshs-00363980}

Submitted on 24 Feb 2009

HAL is a multi-disciplinary open access archive for the deposit and dissemination of scientific research documents, whether they are published or not. The documents may come from teaching and research institutions in France or abroad, or from public or private research centers.
L'archive ouverte pluridisciplinaire HAL, est destinée au dépôt et à la diffusion de documents scientifiques de niveau recherche, publiés ou non, émanant des établissements d'enseignement et de recherche français ou étrangers, des laboratoires publics ou privés. 


\section{0}

\section{Rhythm, accentuation and final lengthening in French}

\section{J. Vaissière}

\section{INTRODUCTION:}

Following tradition and for the siake of convenience in comtrasting linench will other languages, much of he research and theory have assumed han lirench has a stress lexated on the last full syllable of every lexical word, all "accent de mot intrinseyule" (Rousselol, 1924). Lexical words are opposed to funclion words, such as anticles and auxiliaries, which do not have a potentially stressable final syllable (Garde, 1968). In continuous speech, the "accent de nxot" or word accent of a number of lexical words

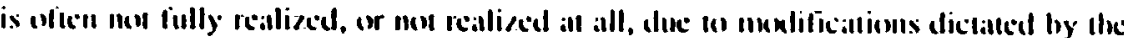

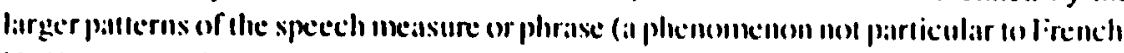
Heffiner, 1950:228). Only the last syllable of the last word in a group of words, lengthened and often superimposed with a fundanental frejuency (lio) rise or a l:o peak as the expression of contintation, is regularly perceived as prominent, giving rise 10 the so-called "accent de grompe" (Deblattre, 1966:75). There is no chear cut detinition

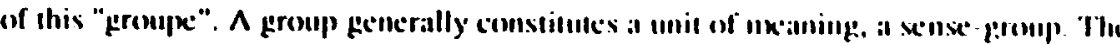

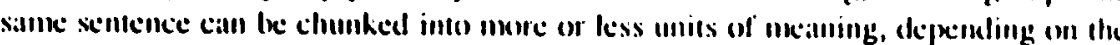
rate of speaking and on the speaker (Grammome, 1914; Coustenoble and Armstrong. 1934; Delattre, 1966:65; Vaissière, 1974:216; Vaissière, 1989; sece also llirst \& Di Cristo, 1984). Prominence can be perceived also alt the beginning of the word, als a

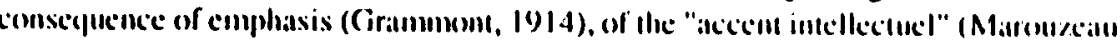

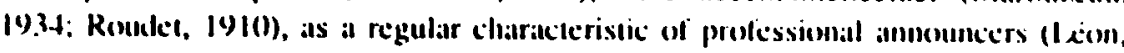
1971: Fonnagy \& Fonnagy, 1976), and in certain dialects (liouche, 1936); Canon, 1976). I have shown that a word initial Fo rise exists at the onset of lexical words, in non emphatic reading of professional (Vaissière, 1971) and non professional speakers (Vaissière, 1974, 1975; Mertens, 1987; see a review by I:onagy, 1980), the relative amplitude of which is speaker dependelli.

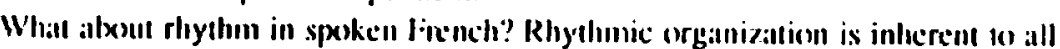
human activity (lashley, 1951), and the observed thythuns proxluced and perecived in

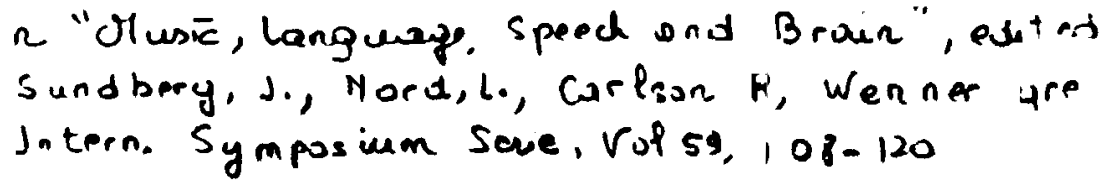

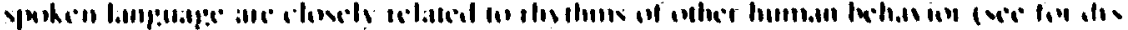

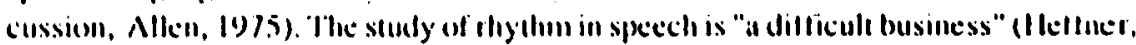
195(): 2(1). The basic principle of rhython is probably independent of the language spoken, and rhyllmon is basecl on llke perception of repealed palkerns composed of successive events. It is related to the notion of periedicity and in siructure (Fraisse, 1956).

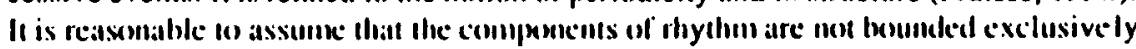
(1) a single percepl, such as the stress ar the syllathe (cf the propusition of bihe, 194.5. of lenglish as a stress-timed langliage with isochronous feet, and French as a syllable-fimed language with isceluromous syllables; Abercrombie, 1967; see Dauer, 1983 and Scon \& al, 198.5. Wenk \& Wiolankl, 1982, for discussions). The repetition of events of different nature (such as a certain sound) can create rhythm (Bally, 1926:255). Moreover the perception of rhythm in a specilic language seems to depend

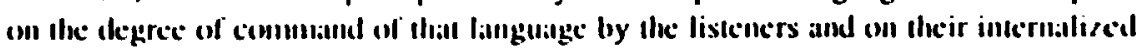
knowledge of the langenalge structure. Rhythun is not only a maller of acoustic measurenkents. The rhy then in Frencls seems very obvious (o) me (as a native of French), much uxore obvious than the rhythm in linglish, where the stream of units of information is thrown into disorder by the intrusion of a recurring strong stress. To a certain extent. stress is felt as all unnecessary addendum wo spukten langlish, an compared to wrillen langlish. The language-specific rules of lirench may indeced not be obvious to non natives. llefiner moles thal "langualges with strong stress are likely so have rhythms of no subtlety whalever; languages which make less use of stress contrast have rhythms which are less obvious. The rloythms of linglish and French, for example, are in many ways comparable to the rhyllums of Sousil and Debussy" (1 leffner, 1950: 227). As a

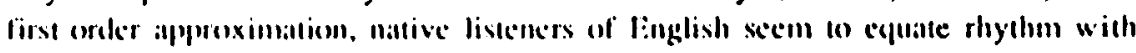

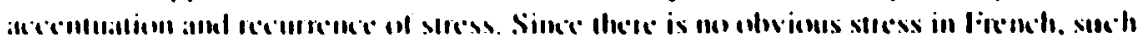
listemers maly have trouble lo grasp a thythonical organisation.

Il may be inleresting to investigille further the reasons underlying the reciprocal difficulity in perceiving and reproxlucing the (wo kinds of rhythm, English and French, and the intrusion of an linglish-like Hyym in Iinech. The conlent of the present paper is also latgely inspited by the work of lraisse. Iraisse is a Iirench psychoikcoustician who hats devoled all his life to the problem of rhythm (in particular, Fraisse, 1956, Les structures rythmicues). Ilis distinction beliveen two basic thythms, "rythmitisation intensive" and "rythmitisaltion temporelle" from experiments on non speech stimuli seems to shed some light on the possible altemattive rhythmic patterns applicable 10 langualges.

The purpose of this palper is threefold: (i) to review the regularities in the prosedy of Irench, which are ilce bases for thyllun; (ii) lo summarize line results of some psychoacoustic experiments, relevamt for tle interpretition of the different rhythus; (iii) to ask whether or not the rhythmic principles of standard, traditional French are undergoing a progressive change. 


\section{I: ACOUSTIC CIIARACTERISTICSOFTIIF TIIRFF. RIYYTIMICUNITS IN} MI()IEERN FIRENCII

There seem to exist three perceptual units from longest to shortest, the repetition of which give rise to a multilayered rlyythus: (i) the repetition and allernation between two hasic global tunes, spanuing over lle breallh-groups, (ii) the repetition of variants of an archetypil prosodic word (PW) pattern; (iii) the succession of typically open syllables $C V$, with a dominating vowel.

It has to be noted that one level may be made nore energent than the others. The regular succession of the snallest rhythmic units, the syllables, can prevail in carefully spoken, slow speech. The recurrence of more or less regular PWS and rhythunic groups. composed of 3 or 4 syllables, may be pue forward in poetry. In rapid, conversational speech, the listeners may direcily perceive the repetition of typical breith-groups.

It is difticult to discollangle the diffierenll units in at purely acoustic study. Ilowever the striking regularities observed in durational and fo pallerning seem to correlatte rather well with the perceived quality of French rhythm. The following description is an oversimplification of the observed facts. The oversimplificition is not only due to a lack of space. According in the Gestalt principle of Pregnïinz, percepts always lend

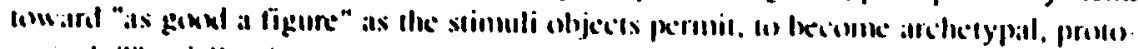

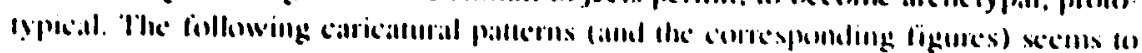
correspond to il psychological reality.

\section{I: TIIE RRE.ATII GROUPS PATTFENS}

The first basic ingredient of French rlyyllun is the alternation of two highly contrastive, rising and falling global piecle comloness at the level of the breath group. BC; There are gencrally pauses between Iwo IBCis, not necessanily accompanied by breathing, and they may not be even present in the acoustic signal. The (wo) global patterns resemble the Iwo well-known Tune 2 and T'une 1 described for Englisl

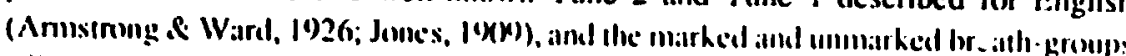

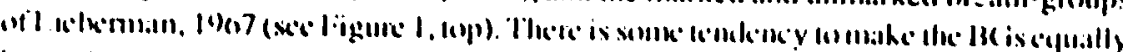

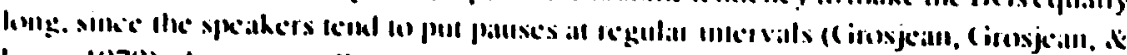
Lianc, 1979). $\Lambda$ lext or a discourse appe:ars tirst as al succession of such pallerns.

The two BGs have in common a rise of Fo mear lleir beginning (Ri) in Fig. I, IOp), on the first syllable(s), and their final syllable is lengthened (a characteristic which exists in different languages, see Vaissiere. 1982 for references).

$\mathrm{BC}+\mathrm{is}$ characterized by a final shapp contmatrion rise on the last full syllable (Re in ligg. 1), preceded hy a low lio vallue (l. in lig. 1) (n) one of llie preceding syllables BG- is characlerized by a large Fo fall (IF), starting from the end of the penultimate werde in ligg. 1) and ending by a very low for villece on the last syllable (VI.).

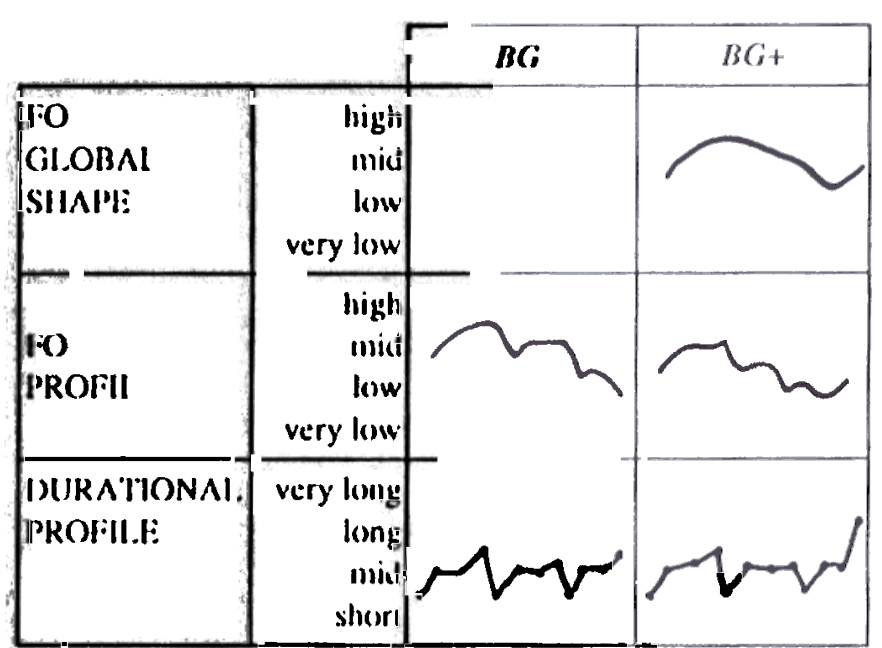

Figure 1: The archetypal brath srotuss and their decomposition into three prossodic words by Fo fluctuations and duration contrasts: the valleys correspond II the function words, and the peaks wo the final sy)llubles of lexical word. The

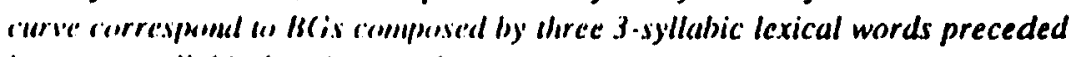
by a monessyllabic: finm siom weord.

The contrast between BG+ and BG- seems largely "exaggerated" in French, as compared (o) English (Delattre, 1966:7.5). The initial rise, the final fall and the continuation span their effecl over several syllables, whereas in American English, most of the loc changes occur withill a single stressed syllable and most of the BG+ end with a filling intonation followed by a sunall rising hook, and very few by a clear rising intonation (10\% accoraling (1) Pikc, 19.15: 15.54).

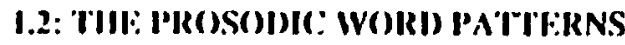

L.ong B(is are prosondicially substructured by an oscillation of the pitch between the high register and the low register and by durational contrasts (See Figure 1, bottom). The rise and the fall lend to succeed in a rather regular noanner (Vaissière, 1974, 1975, 1982). The combinalion of a successive rise and fill and a durational peak roughly correxponds (1) a PW, in French as well an in other languages (see Vaissière, 1983 for referellices, discussions and exannples). The correspondence between the rises and the falls and the characteristics of the words depends on the language. In French, the rises and falls are direcily related to the word boundaries, as established by the tradition, and not to stressed syllables, like in IEnglish. 
The very basic principles of allernation atre the following. Iirst, lexical words contrast with function words by pitch: they tend to be uttered on the high register and the function words on the low register (for detailed rules, see Vaissière, 1974, 1975). Second, there is a strong durational local contrast between the final syltable of a lexical word which represents a local peak of duration, and the followving shore function word (a valley in durational profile). As a consecfuence, the most typical bounclary in Iraditional French is acoustically marked by a change from high to low register accompanied by an local acceleration of lempo.

The repetition of the same PW and of the same boundary markers increases the sensation of rhythm at the level of the BG. The successive PWS maty however differ by their global shape and their final pitch.

The decomposition of the BG into PIVs and the choice of the variant for the PW follow some general principles:

1) long lexical word (consisting of 3 syllables or more) of ten corresponds on a single PW. Semantically related short words, stch as a noun followed by an adjective, tend of be regrouped into a single PIV, and this cin be allributed to a tendency toward unifom size of the PWS in terms of number of syllables

2) the detailed Fo pattern of each PW depends on its length and on the glide associated with its final syllable, which can be rising, flat or falling. The initial rise at the word beginning is extended to the following vowel and syllable depending on the strength of the underlying segments (sece cximly)es in Vatissière, 197.8:25.3: for a measurenent of the strength of the phomemes, Delattre, 1960:112). There is a feature hierarchy for the realisation of the PW and the lune on the final syllable is given priority over word initial rise (Vaissière, 1974, 1975, 1983).

3) the choice of the glide on the final syllable depends on two factors. First, the degrec of dependency of the word with the following word: a peilk pattern, with rising glide expresses independence (corresponding to the "comtinuation" of Delattre),

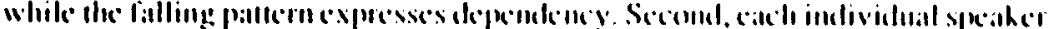

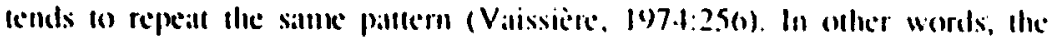
strength of the boundaries is symtix dependellt and speather vartable.

As shown in Fig. 1, the melodic and duration profliles lend to be basically rising. from short and low (corresponding (o a function word at the rhythmic group le ginning) (o) high and long syllables (corresponding to lexical word final syllahles; sec also Delattre, 1966; Touati, 1987), with a plateall on the inlermedialc syllable(s) (corre sponding to the lexical word non final syllables).

Such an increasing durational pattern is disturbed by the following conflicting influences:

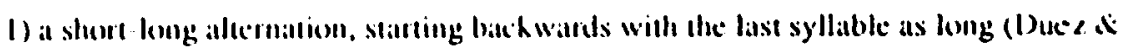
Nishinuma, 1984).

2) a slight tendency of the word initial consonant to be lengthened, particular in the cisce of unvoiced stop consonamts.

3) a temdency for the licavier syllathles (closed syllables and syllathles with natsil

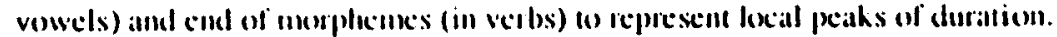

4) a relative lengthening of the penultimate syllable, which may be perceived as a mark of regional accent (Catom, 1967).

5) the intrinsic and cointrinsic influences on the duration of each segment (see Di Cristo \& Hirst, 1986).

The tendency wallernation seems o be "an exatggerated" feature in Finglish, and has given rise lo important theoredic:al develepments in the metrical theory (liberman ant l'rince, 1977, anong others), In lirench, lhe word initial rise bounded to the onset of PW of more than (wo syllables (Vaissière, 1971, 1974) seems of greater importance than the alternation principle.

In terms of size, the PW probably correyponds to the stress group level in English Isckhrony between stresses in Finglish which is known lo be essentially a perceptual phenomenon with a psychological reatity (Leat, 1974, L.ehiste, 1977) probably corresponds wo the tendency for the rise and fall composing the PW wo succeed evently (See the work by Fant and coworkers, $199(0)$ and forthcoming, showing a similar tendency in Linglish. Swedish and French to make prominence crop up at regular intervals, around $5.50 \mathrm{~ms}$ ). The lack of one clearly prominem syllable in the PW makes it less perceptually satient than the stress group, where the stressed syllable constitules an anchor point

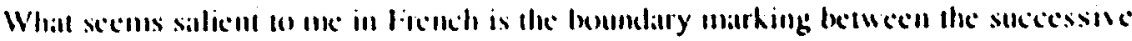
PWV. The smaller saliency of the P'W in Jirench gives more room for the lower unit, the syllable, lo play a domininant role in perception.

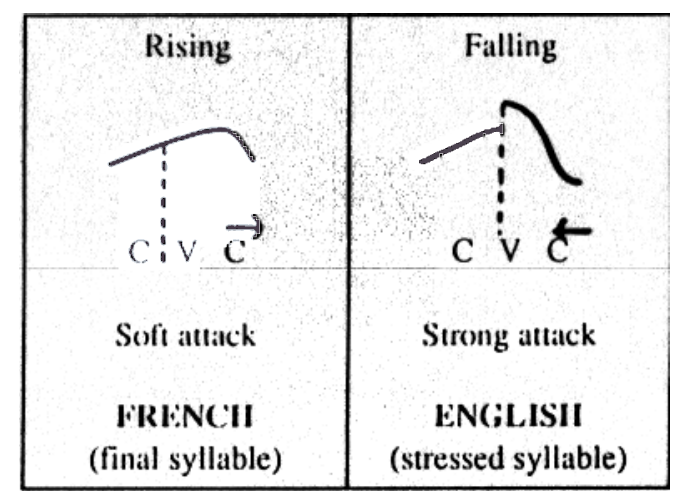

Figure 3: The archerypal sylluble: the curves pertain to the general impression of the e'olusion of tension, and the shate are also typical of the foo glicle during the find syllables in Fremch and the stressed syllables in English. 


\section{3: THE: ARCHI:TYPAI. SYILABI IN RRI:NCII ANI) ITS VOCAI QUALITY}

Among the major linguistic factors which contribute to the subjective impression a listener experiences concerning rhythm, one is certianly related to "le mokle tendu" and "le mode croissant" (Delattre, 1960:9), and the relatted characteristics such as the soft attack of the vowels, and the basic CV syllable (see ligure 2 for a very impres. sionistic sketch).

a) Le mode tendu: Phonation is perceived as particularly tense. There are no affricates, no lax vowels, not nuch reduction, no diphthongs and no diphthongized vowels (Delattre, 1966: 323), and the vowels are ofien considered as close to the cardinal rowels as defined by Jones. Intensity tends wo stay constintu, despite eventual chantes in Fo and duration. The guamlum of muscular energy which gexes into each syllable seems equal, at least in non emphatic speech.

b) Le mode croissant: French syllables seem predominanly rising, with the vocial Iract opening progressively up to the very end of the syllable, which typically end

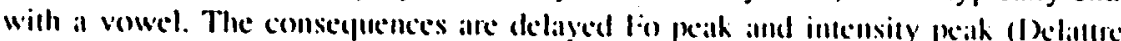

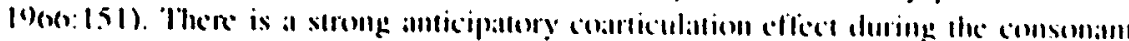

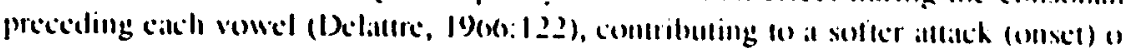
the vowel, as compared to English. Inside a PW, the syllable-final consonam tends to link with a following vowel, increassing the number of open syllables.

c) The number of open syllables prevails in Frem.h (76\% according on Delatlre, 196.5:42, and most of the syllables have the simple structure CV $(5.1 .9 \%$ : the most

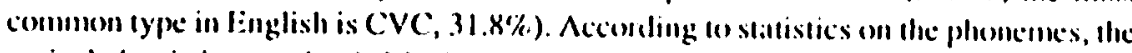
ypical phomic impression left by french would le a dental with strong fromt resonance (Delattre, 1965:61). In English, the greater length, larger complexity and the larger variety of the syllables (61)\% close syllables and $40 \%$ open syllables) make the syllable a less clear psychological reality than in French, according to the laws of the (iestialt Theory on "pregnant" forms.

Such subte differences in syllable anticulation are diflicult wo quantify. Nevertheless they might be very important perceptual fealures. Note that there is a certain similarity between the CV syllable rising stereotype for French syllables and the basic rising stereotype for French disyllabic words as proposed by Grammont for intensity (Grammont, 1914), pitch and cluration Delattre (196.5:23), on one side, and the two falling stereotypes with strong vecalic onset for the linglish syllable and the falling lio paltern on English disyllabic words with primary stress on initial syllable. As noted by Delattre (1966:25), French gives a rising impression, and English a falling one.

The pregnant speech paltern stored in speakers' memories influences the way they perceive the different languages (See Delittre's exillmples, 196.5:23). P'sychoalcoustic results seem to reveal that French and linglish archelypat patterns, appiarently very different. may be two variants of the realisallion of a universal patlern.

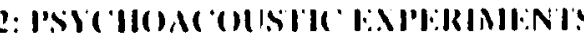

As staked in the innokluction, thythunic effects derive from universal organizing principles of humban perceptual and molor beloavior.

One of the main comclusions drawn fiom psychosucoustic experiments is that grenping is a funclannental chatratederistics of perception (tiraisse, 1974:74). Secpuences of eyually spaced, identical tonc bursts appe:ar of be regrouped into units of 2,3 or 4 and perceived as rhythmic (Woodrouw, 1951: Fraisse, 1974:82). This may explain the relatively short size of the stress group in linglish and of the PW in French. The speed of succession of the bursts inflecences the preferred size of the grouping: the more rapid the succession, the grealler the number of elements in the group (Bolton, 1894, cited

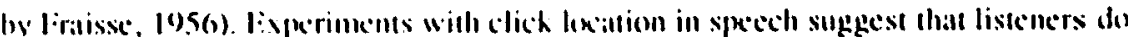
mil deal with each somed sepallatlely but tather with a group of sounds (ladeloged 8 Broidelle:IIt, 19(x); Ioder \& Bever, 196,5).

Once subjectively regrouped, the first burst of the group is perceived as accented, the last interval, which becomes the interval boundary, is perceived as longer. One of the lwo phenomena (initial atcentuattion or final leng(lening) may receive perceptual dominance. In linglish and licench, initial atcentuation and final lengthening seem to

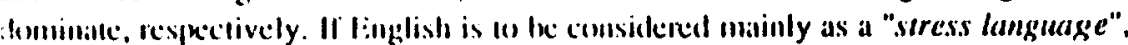
then linench should be considered mainly as a "lonumdery language". Lengthening is also used in English ats a boundary marker (Lehiste \& al, 1976). Initial accentuation in French is realized by the word initial rise in non emphatic reading, and it becomes perceptually domintant in comphattic specth. But what is generally prevailing is the

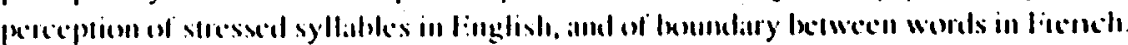

l'sychoalcoustic experiments on tone burst have largely confimed the role of a longer interval or of a clongation of a pulse as a lefi boundary marker, the role of accentuation (by increase intensity or pitch) as a left boundary marker, and the tendency to perceive as isochronous the elements inside a grouping (Woodrow, 19.51; Fraisse, 1950 and 107.t for a stmmintary and references and Allen, 1975). An lio jump on the first syllable alter a strong attack is perceived as an increase in intensity, but not as a jumlp) in pitch (Séguinot, 1976).

If a pulse is made longer that the final pulse, regrouping occurs, and the longest element becomes the final element. This may explain why word initial pitch jump in Fiench is done without increasing much the duration of the underlying initial element (Fo junp and lengthening kend of be associated in lenglish), and why duration is less and less used distinctively for differentiating the vowels.

Not all speakers, however, reatct in the same waly when presented with the same stimuli. When some elements are more inense, the majority of listeners perceive the boundary before the accented burst ("rythunitisation intensive", according to Fraisse, 
195(1). One third perceive the accented burst ats group findt. The last catcegory of listeners seem to overestimate the interval af ter the accented burst, and inlerpret llo lengihening as a left boundary ("organisation lemporelle"). Bollo rhythuns may coexist in the same speech material, and their coexistence makes it more difticult Io pereeive rhylhmicatly. The inherent ambiguity between accentuation and induced lengthening may explain why French seems to avoid a strong accentuation of final syllables, and overlengthening of one syllable in the group, except the final one, which can be lengthened almost at will, but also very little. If $(00$ alcented, the fintal syllable may be perceived as group initial. If one syllable becomes longer than the final syllable, it may be perceived as group final. It also explains why comphatic stress in lirench falls on llec word initial syllable: strong alcentuattion is psychologically more compiatible with word beginning than word ending. It should be also noled that stress languages (like linglish, Giermatn and Spanish, see Delattre statistics, 196.5:31; Cutler and (arler, 1987) have very few s) llables with linal stress. In other words, accentuation and final pesition are less compatible than accentuation and initial syllables (sce work on final lengthening as boundary marker in English by Klatt, 1976, Culler and Bullerfield, 1989, and Buttterfield \& Culler, 1988, on segmentation errors in English due to the insertion of a

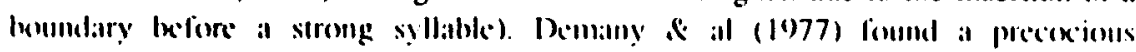

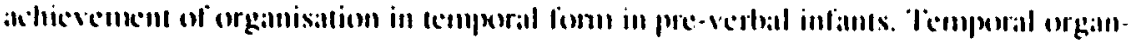
izattion seems (1) appear earlier in child development than intensive "rhythmization". linglish children polysyllabic ullerances soment typicilly syllable-timed (Allen \& Hakwins, 1978). Final lengthening appeats in the speech of French children at the age of 24 months (Konopzynski, 1988; see also, Oller \& Smith, 1977). All these phenomenat are collerent with the idea of a superposition of two relalted basic rhy thuns, as described by Fraisse. Moxdern French seems to le all example of the confusion created when lhe iwo rhyllums coxexist.

\section{3: TIIF 'WO RIIYTIIMS IN M()IFERN IRRENCII}

Prominence on final syllables ivis generally considered to be the rule in non emphatic lineme.h. There is however a leng series of palpers stating in the previous century which question this traditional point of view (see Fonagy, 1980), for a review). Some pho. neticians considered as 'désagréable'. 'vulgaile' or as a pronunciattion corror the displacement of the prominence to the beginning of a word. Many plometicians simply ignore the fact. Many books mention that "correct Frencli" should avoid to put some syllables more prominent than others. The description of a regular initial rise at PIV onset in texts read by non professional readers willout regional adcent ( Vaissière, 1974. 1975) was a sort of surprise. Most of my colleagues interpret the excurrence of the initial rise as an expression of emphasis, or joumalistic style, and contimue to ignore the fact in their description of standard (non emphatic) lirench proserly. The frecpuent prominence of the word initial syllable was however moticed by Jonlgy, matinly in periceptuil axperiments.
In their paper, "I’roscodie prolessionnelle and changements phonétiques" (Fonagy

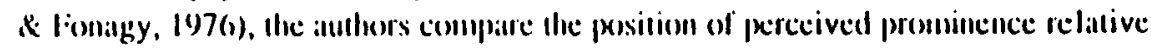
(1) the word boundaries in different slyles. In a very small number of cases (less than

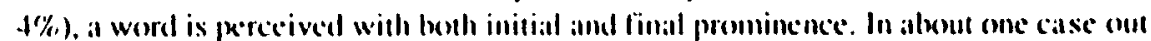

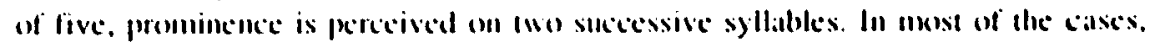
following the tratlitional point of view, prominence is perceived on the fimal syllable: 75\% for conversational speech, 72\% in story telling, and 64\% in TV news-reading (page 202). Two degrees of prominence were distinguished. While in conversattional speech and story telling, finlal syllables were perceived as more proninent than initial syllables (oxytome scheonk), in jourmalistic style, initial syllables were perceived as

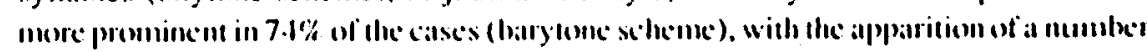
of glottal stops characterising word initial vowels (207). The authors note a certain analogy between the styles of the French and linglish radio announcers (215). They conclude that initial accentuation which is considered as expressive (emphatic stress) in non professional speech, becomes a regular characteristic of the style of radio announcers. The distribution of prominence is much less regular in news reading than in the two other modes (20) and lle most freyuent spacing between Iwo prominences is spe:aker dependent. While in conversational speech and story telling, the function words are generally mol perceived as prominent, in journalistic style, a prominence can tre perceived on the very first elemeill of the shythmic group, a function word (203). The probability for a function oo be accented is 10.0 .3 in story telling, but 0.42 in news reiding (Fonagy, 1980): 160)). The probability of a word initial prominence depends on the speakers (for political speeches, see Duez, 1978: 79). French listeners are not consistent in detecting prominence, and it is a difficult lask for them (Fonagy, 1980) 1.30). For lonnagy, the present-day French prosexlic system is in the process of a change the variability may be the expression of this on-going change.

\section{CONC IISION}

This contribution has becon based on the investigation of the particularity of French rhythm. Oversimplified palterns at three different levels, the breath group, the prosodic word and the syllable are proposed as reference patterns. The first layer, the breath group layer consists in the repertition and allemanton between two highly contrastive global tunes, which resemble Jones' line $I$ and Thene 2, but the difference between which is extremely exaggeraled in French. The second layer concerns the repetition of variants of an archetypal prosedic (PW) word pattern, shaped by the successive oscillation of the pitch between the high and the low register: the striking fact is that in French the up and down of pitch oscillation are bounded to boundaries. Both duration and pitch seem typically to increase from the beginning to the end of the thythmic group. The last layer is the succession of typically open syllables with a simple CV struclure, characlerized by their lenseness and rising mode. Large references to | delantre's work are made. 
Both the prosodic word in French and the tone group in Finglish are interpreted as two variants of the same archetypal psychological pallern which assexialled accentuation with the beginning and lengthening with the end. Iraisse' work on the possibility of differently regrouping the same stimuli depending an "intensive" or "temporal" "rhythmization" are exploited to explain both the differences between French and English basic rhythm at the level of the PW (for French) and the tone group (for English) and the intrinsic ambiguity of the present-dily rlyythm in French. The tone group in English is interpreted as a variant of the arclietypal pattern where accentuation is dominant, and lengthening recessive. In the lirench PW. Emporal orgamisation is predominant, but initial accentuation is also intrinsically present (cmphatic stress and initial rise) leading to some confusion in the present-diny scheme of Irench prosoxly. If English is to be interpreted as a "stress langurnge", firench should be cilled at

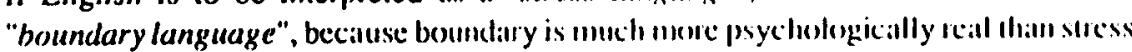
for French (at least, for me!). It would be interesting 10 investigale low basic psychological constraints are integrated into the prosody and rhythm of other languages.

Acknow ledgement: / thank very much Danielle Ducz for her help and fruifful discussiens am Fraise

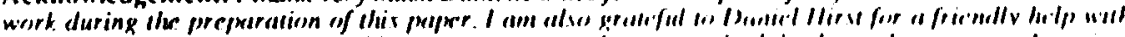

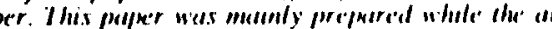
Professor at the Insituce of Phonetics of Aix.rin. Proverent

\section{RLIIERENCWS}

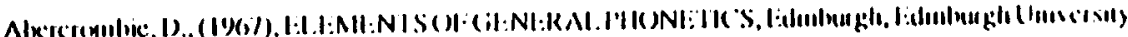

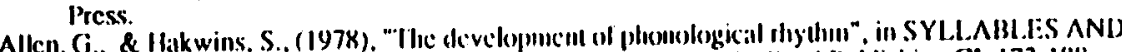
SI:GMENTS, A. Bcll, J. Hopper, (cals), Antisterdam: North Itollauml Publishing C", 173-188.

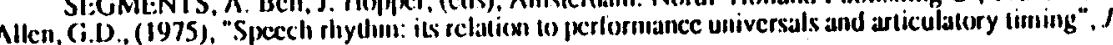

作

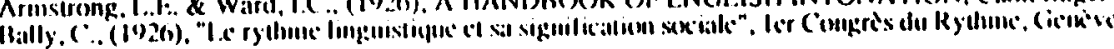
253.265 .

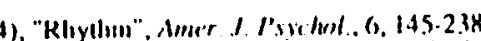

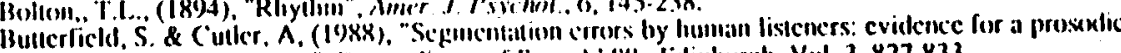

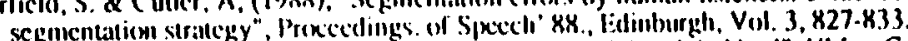

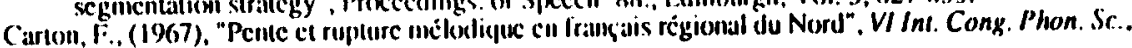

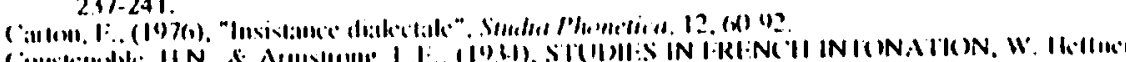

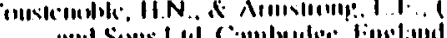

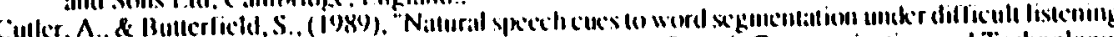
conditions", Eurossecech 84 , Europxan Cunterence on Speceli Communication and Technology. Paris, Vol. 2. 372.375

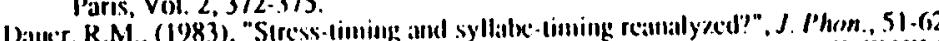

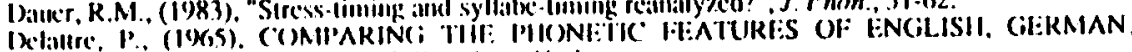

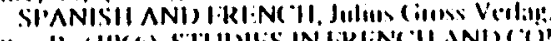

12.

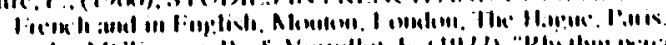

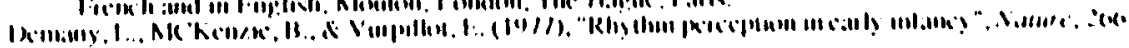
(2) $7,718.9$

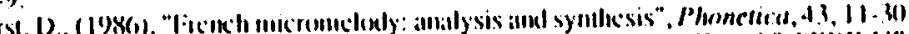

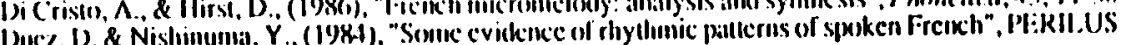
(1) $84.5,30.40$.

Duc Univ, de Paris III.

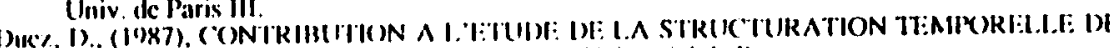

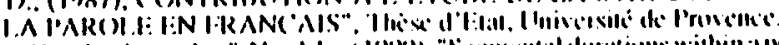

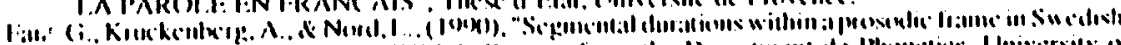

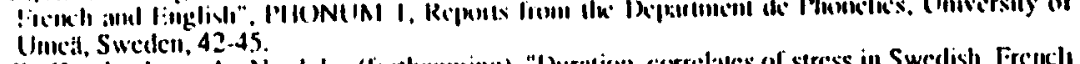

Fant, G., Kruckenberg. A., Nord, L., (lentheoming). "Durition cerrelates of stress in Swedish, French and Englisli", in Procedings of the Second Scminilr on Specth Production, Lecds, May I9x).

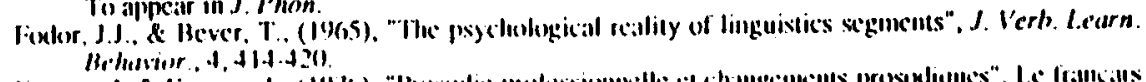

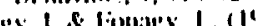

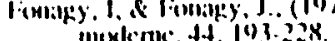

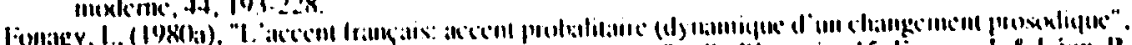

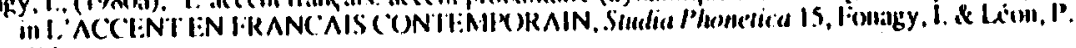

(lids.).
Fouché, P., (1936), "Les diversess sonces de français Au point de vue phenoúlique", Le Français Moderne.

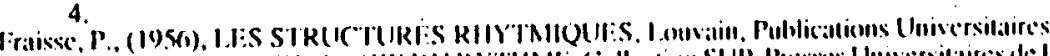

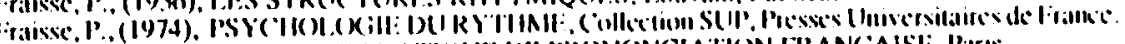
ACIATION FRANC AISI:, P'IIIS:

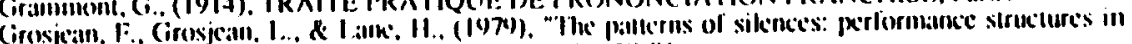

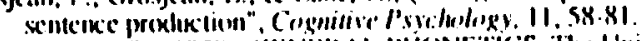

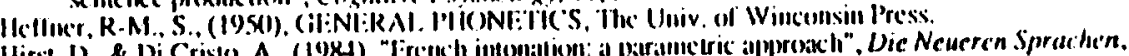
X3.5.554.569. 


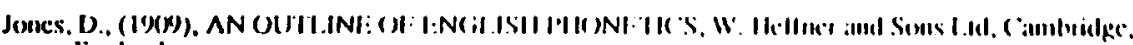
England.

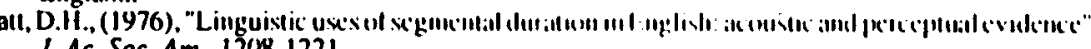
Konopcynski, G. (1988), "Lcs oprosi.

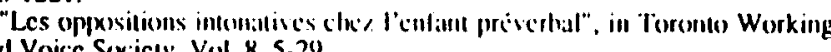

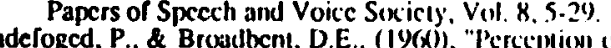

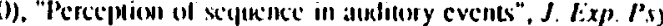
LCa, W.A. (1974), PROSODIC AIDS TO SPIETCII RECCKINITION: A SUMMARY OF RESULTS TO DATE. Sperry Univac Techmical Report. No. PX 11 (187.

Lchistc, l., (1977).

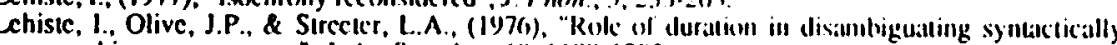
ambiguous sentekces",J. Ac. Sec. Am., (x), $11(x)$.12(0)

Léon, P.. (1971), "La jonc lure externe cri franģäis: Hallure cl lenctions linguistiques el expressives", Essai

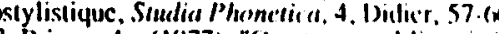

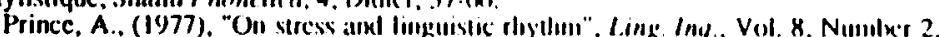
249.336

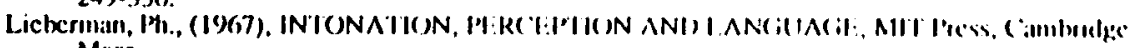

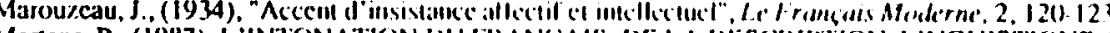
MenCnS.P.. (1987), L.INTONATION DU IFANC AIS: DI: LA DI:SCRIPIION LINGUISTIOUE A

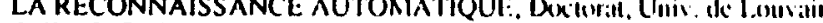

Oller, D.K.. \& Smith, B.L., (1977). "Elfecl of fintal-sylliatle position on sowel duration in infant

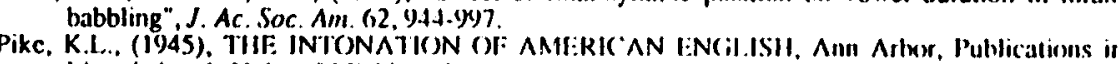

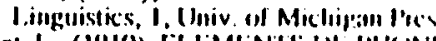

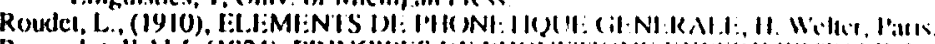

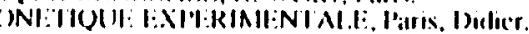

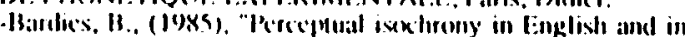
French

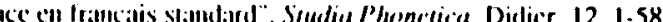
STRUCTURLS PROSOIDUUI:S DU SUI:IXIS ITT DUIRANCAIS, PROFILS

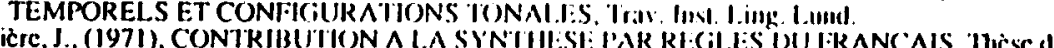

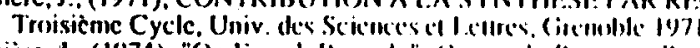

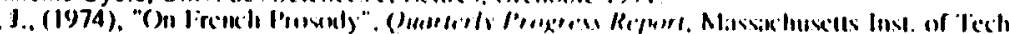

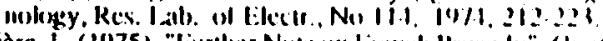

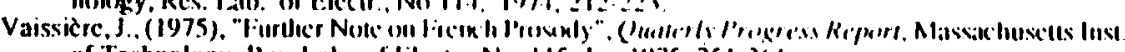
of Technology. Res. Labl. Wf I:lectr. No. I15, Jan 1975, 251-201.

MEASUREMENTS A COLY MOULLS AND

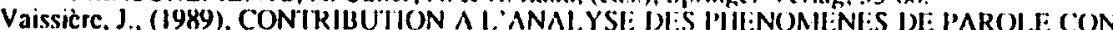

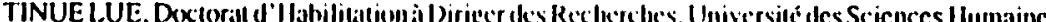
de Strastourg.

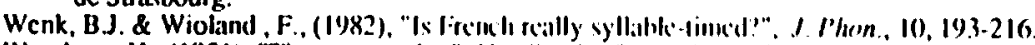

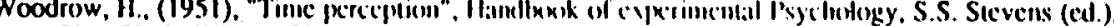
Ncw-York: Wilcy, 1224.123\% 